\title{
CREATING THE HUMAN CAPITAL OF THE GLOBAL CITIES. FIRST STEP: EQUAL ACCESS TO QUALITY EDUCATION OPPORTUNITIES
}

María Balzaretti Tejedo

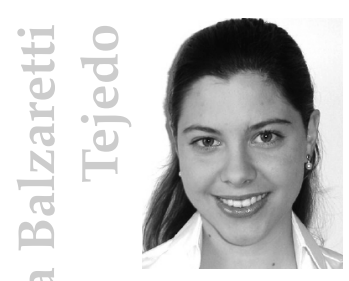

Posgrado en «Global Cities», Northwestern University, Chicago; Universidad Panamericana, México; Tong Ji University, Shanghai; y Sciences Po, Paris. Licienciatura de Administración y Mercadotecnia, Universidad Panamericana. Estudios en Alemania y Canadá. Se ha especializado en la investigación comparativa sobre la creación y desarrollo de capital humano en las Ciudades Globales, y en el estudio del rol público y privado en la educación. Correo electrónico: [mariabalzaretti@gmail.com].

\begin{abstract}
Global cities' economic development depends highly in innovation. Therefore, the human capital is the raw material of the Global Era and a successful city is the one that creates, attracts and retains its human capital. The first step to create the human capital is to provide equal opportunities to quality education. However, because of insufficient taxes and large sudden immigration flows that come to global cities, most governments lack the infrastructure and capability to provide these opportunities to all children and, in addition, they consider low income and immigrant children as a high cost problem instead of as a great potential that requires investment. This is when civil organizations emerge to fill the government's gaps by providing education and development opportunities. This research analyzes the public and private
\end{abstract}


roles in education through a case study: Mexico City and Paris are considered opposite examples of educational systems in terms of government's participation, whereas Chicago has managed to hold a balance among public, private and civil organizations contribution model that has helped the city upgrade in the education rankings. The best way to keep improving the education quality and equal opportunities is to create consensus, combining civil organizations' expertise and ability to attract the media attention, with the political will of the government and the commitment of society in order to generate chances for effective social policy making in terms of education.

Key Words: human capital; equal opportunities; quality education; government; civil organizations; consensus.

\section{RESUMEN}

El desarrollo de las ciudades globales depende en gran parte de la innovación. Es por eso que el capital humano es la materia prima de la Era Global. Una ciudad exitosa es la que crea, atrae y retiene su capital humano, y el primer paso para la creación del capital humano es la igualdad de oportunidades para una educación de calidad. Sin embargo, por falta de fondos y grandes y repentinos flujos de inmigración, los gobiernos no cuentan con la infraestructura y capacidad necesarias para ofrecer estas oportunidades a todos; además de que los niños inmigrantes y de bajo nivel socioeconómico son considerados un problema costoso en lugar de un gran potencial que requiere inversión. Es aquí cuando surgen las organizaciones civiles que tratan de llenar estos gaps del gobierno, ofreciendo oportunidades de educación y desarrollo. Esta investigación analiza las relaciones de la participación pública y privada en la educación mediante tres casos de estudio: la Ciudad de México y París son considerados sistemas opuestos en cuanto a la participación del gobierno en la educación, mientras que Chicago se encuentra en el punto medio ya que posee un balance entre la intervención pública, privada y las organizaciones civiles, modelo que ha impulsado la calidad y el desempeño en la educación. La mejor manera de optimizar la oferta de educación es crear consenso entre los sectores, combinando el expertise y la habilidad de las organizaciones civiles en atraer la atención de 
los medios, con la voluntad política del gobierno y el compromiso de la sociedad para generar posibilidades de crear leyes efectivas en materia de educación.

Palabras clave: capital humano; igualdad de oportunidades; educación de calidad; gobierno; organizaciones civiles; consenso.

\section{INTRODUCTION}

«We called for guest workers and we got human beings».

Max Frisch, 1950's.

\section{Global Cities and People}

Human Capital Development is the greatest challenge a Global City has to face in order to compete in the global era. It is important to understand the meaning of a global city and the vital role people play in order to make it successful. Cities are the places where people come together to trade goods, money and ideas. But, the most successful cities are those richest in people: smart, diverse, innovative, hard-working and productive people ${ }^{1}$. The term "global city», coined by sociologist Saskia Sassen, refers to a city that serves as a control center for the new global economy. A global city is where the coordination of people, money and services take place, even though resources are spread across the globe. It also is the place, with the workforce, that takes this creativity and turns it into products, exports and services. Therefore, we could say that the human capital is the raw material of the Global Era. The urban center of a global city is a mix of firms, talent and expertise located near each other to facilitate their complex interactions, but how do global cities develop all these talented, highly educated, skilled people? In other words, what are they doing to attract or create their human capital?

1 The Chicago Council on Global Affairs. The Global Edge: An agenda for Chicago's Future., 2007, 43. 
A global city can develop its human capital by attracting it or by creating its own. A successful city does both. This research studies the investment in the creation of human capital, through equal education opportunities and development of the low-income, immigrant children that are born or brought to the global cities as such as Chicago, Mexico and Paris, as a potential force that generates economical, political and social power giving the city a competitive advantage and strength by being competitive and able to take advantage of the jobs a Global City can offer, reinforcing its economy and helping it succeed in the Global Era.

When public funding is not enough for a Global City to prepare their future taskforce providing quality education to all children, civil organizations are created in order to substitute this government's role. The participation of these organizations is crucial to the development of the children from low socioeconomic families and also to promote policies for equal education opportunities by contacting and helping legislators in developing global cities like Mexico and Chicago.

The government and civil organizations should be working together to offer a better and equal education system for all children. But what is being done in global cities like Chicago, Mexico City and Paris in terms of public funding for schools? Aiming to contribute to the debate of the importance of the creation and development of the human capital in a global city, this study analyzes the relationship between the state and organizations in each city and their role in providing equal education opportunities.

\section{LITERATURE REVIEW}

\section{The Human Capital Concept}

In order to understand the human capital development debate, it is important to first define and comprehend the concept. Human Capital is defined by the Organization for Economic Co-operation and Development (OECD) as: «The knowledge, skills, competencies and 
attributes embodied in individuals that facilitate the creation of personal, social and economic well-being» ${ }^{2}$.

Traditionally, many economists explained that economic activity happened because of Adam Smith's factors of production ${ }^{3}$ : Land, capital goods and labor (a fourth factor, entrepreneurship, was added in the early twentieth century). Adam Smith refers to labor as «human capital» which he saw as the skills, dexterity (physical, intellectual, psychological) and judgment. Smith believed that economic activity was fuelled not by workers as a collective mass but by «the acquired and useful abilities of all the inhabitants or members of the society». His idea that worker's individual capabilities were a kind of capital, started to be significantly incorporated by economists until the 1950's. A. W. Lewis is said to have begun the field of Economic Development and consequently the idea of human capital when he wrote in 1954 the «Economic Development with Unlimited Supplies of Labor».

The use of the term in the modern neoclassical economic literature dates back to Jacob Mincer's pioneering article «Investment in Human Capital and Personal Income Distribution» in The Journal of Political Economy in 1958. The best-known application of the idea of «human capital» in economics is that of Mincer and Gary Becker of the "Chicago School» of economics. Becker was awarded the Nobel Prize in Economics in 1992 and his book entitled «Human Capital», published in 1964, became a standard reference for many years. In this view, human capital is similar to "physical means of production», like factories and machines: one can invest in human capital (via education, training, medical treatment) and one's outputs depend partly on the rate of return on the human capital one owns.

Many early economic theories refer to it simply as labor, one of three, and consider it to be a -homogeneous and easily interchangeable. Other conceptions of labor dispense with these assumptions. There has been a

KEELEY, Brian., Human Capital: How what you know shapes your life., OECD., 2007., 29.

SMITH, Adam., The wealth of Nations., 1776. 
debate about the concept. Some philosophers, sociologists and economists argue that the terms «Human Capital» and «Human Resources» suggest a depersonalization of the individual and are associated in the popular mind with a dehumanizing society that equates humans with machines, and that it should be called «human factor» or «personnel». To the contrary, others argue that the «human capital» concept is correct because it «recognizes that human beings are as important as physical capital in creating wealth and generating a successful economy» ${ }^{4}$.

However, it is the term capital that has been distorted when we refer to it as money or assets. Because the word capital comes from the latin «Kaput» which means head, and it is from there where the keys to development come: planning, innovation, productivity and active participation come. So, development is always related and dependent on human capital and this study will refer to it as the knowledge, skills, competencies and attributes that a citizen (native or immigrant) of a global city needs to develop in order to become competitive and improve its quality of life and his community.

\section{Global Cities and Human Capital Development}

The consideration of human resources started in the field of sociology. In 1906 Frank Ward studied the origin and environment of talented men, as well as their implications for social welfare and he concluded that there existed mines of undeveloped human resources in society. By 1926, Strow argued that the importance of the human factor in social life was at last coming to be truly appreciated ${ }^{5}$.

There is also an important global debate for this research to talk about, regarding the fair distribution of human capital. This concept is mostly about educated individuals, who typically migrate from poorer places to richer places seeking opportunities. Human capital, as the skills and knowledge of people, is one of the key assets for the development and

4 HECKMAN, James J., China's investment in Human Capital., University of Chicago., 2003., 796.

5 STROW, Carl W., Human Resources for Community Welfare., 1926., 562. 
growth of a country. Human Capital distribution has always happened, but in this Global Era people increasingly work abroad, often pulled by opportunities in richer countries, or pushed by a lack of these in their home country.

International labor migration can bring benefits to both developing and developed countries. Filling in critical labor gaps in richer countries, migrant workers can also contribute to reduce unemployment and demographic pressures in their countries of origin. Emigration countries can benefit from the financial and other contributions of migrant communities, which can help increase income for the poor and develop the knowledge base in the countries of origin ${ }^{6}$. But besides development opportunities, international labor mobility can also present risks. Highly skilled emigration from developing countries («brain drain») can also have negative effects on sectors critical to achieving development goals in the countries of origin, depriving key sectors as health and education of qualified people. Some countries address this by efforts to better retain, re-train and regain brains.

Today we are aware that economic success of a Global City relies on human capital, the knowledge, skills, competencies and attributes that allow people to contribute to their personal and social well-being, as well as that of their countries. A Global City can get its human capital, in two ways: the city can create it itself, through its educational system or it can draw it from outside by becoming the kind of city where the best and the brightest want to work and live. A successful city does both. The keys to creating, attracting and keeping human capital are education, quality of life, good jobs and diversity.

\section{The Role of Education}

Globalization has created an increasing gap between the rich and the poor. In global cities the underclass gets segregated and gathered in specific

6 Global Forum on Migration and Development., theme 1. 
neighborhoods making vulnerable regions that generate more poverty and with a lack of public services that prevents them for getting an appropriate education system. Segregation intensifies and magnifies the economic setbacks these groups suffer and builds deprivation structurally into their social and economic environments ${ }^{7}$, and the process is cyclic.

A basic result of economics is that resources should flow to their most productive use. Human Capital is productive because of its immediate effect on raising the skill levels of workers. James Heckman's research summarizes evidence indicating that the true rate of return to education and skill formation is very high ${ }^{8}$.

People with better education tend to obtain higher incomes, which is a benefit that is also reflected in improved economic growth and has an impact that favors cities beyond economics because it raises health levels, community involvement and employment prospects. Therefore we can say that the key factor and first step in forming human capital is education.

Even in developed countries, too many children today are not being given the chance to get education opportunities and fully develop their abilities ${ }^{9}$. Education has an impact on the quality of life of the citizens of a global city, and by improving this, starting with equal education opportunities, cities can develop better human capital which is one of the most important components to grow in the globalization era. In order to improve, the government, the organizations and the citizens have to work together to create a synergy that improves the economy of the global City and keeps it being innovative, strong and competitive.

MASSEY, Douglas S., American Apartheid: Segregation and the Making of the Underclass.

8 HECKMAN, James J., China's investment in Human Capital., University of Chicago., 2003., 795.

9 KEELEY, Brian., Human Capital: How what you know shapes your life., OECD., 2007., 3. 
These human capital problems in developing societies are mostly the result of two major issues. First, rapidly growing population ${ }^{10}$, which is most time associated in Global Cities to the huge immigration flows that arrive to global cities, including children, when the city does not have the capacity to receive and educate them properly. Second, and most important, the lack of public funding to provide equal education opportunities to all children. This is when Civil Organizations emerge to fill this resource gap and provide education opportunities.

Theodore Hershberg thought that «highly developed human capital will be the source of comparative advantage in the twenty-first century global economy» ${ }^{11}$. He also argues that "problems in America's human capital development are found in education: system K-12, post-secondary vocational training, higher education and on-the-job learning that must be corrected if a nation is to compete effectively» ${ }^{12}$.

Education, skill levels, and problem-solving abilities will enable an individual to be a productive worker in the global economy of the twenty-first century. We have to make sure that the children are developing the skills required by the jobs of the twenty-first century global economy. Human capital development to create a future labor force that can compete successfully is one the greatest challenges facing all cities that want to be global and competitive.

\section{The Role of Civil Organizations}

When states become dysfunctional in providing education opportunities, the third sector (institutions formed with social capital) take on their role. To move toward economic and social well-being, states must

${ }^{10}$ HARBISON, Frederick., Educational planning and human resource development., UNESCO., 1967., 26.

${ }^{11}$ HERSHBERG, Theodore., Human Capital Development: America's Greatest Challenge., 1996., 1.

12 Idem. 
support inclusive development: the government, civil society, private business and citizens should work together with an integrated approach and concrete goals and strategies ${ }^{13}$.

The third sector refers to the sector of the economy that is not run by the Government or the private sector and it involves civil organizations. Since economic, social and legal systems vary widely, the scope, form, and understanding of third sector or civil organizations also varies from country to country, and even within countries there is sometimes debate over what the sector contains. The rise of the non-profit and nongovernmental third sector is a recent and massive phenomenon that is paving the way for unprecedented forms of interaction and regulation between civil society, the State and the market ${ }^{14}$. A non-profit organization (NPO) is a legally constituted whose primary objective is to support or to actively engage in activities of public or private interest without any commercial or monetary profit purposes. This research will focus on the NPOs that are active in the education for underprivileged children in global cities.

It is important to understand the social capital concept in order to explain how civil society organizations are funded, supported and their importance to achieve improvement in communities. Today the idea of social capital was developed by James Coleman, Pierre Bourdieu, Glenn Loury and others as a heuristic way of referring to elements of social structure, such as trustworthiness, information channels, authority relations and norms, that serve to facilitate collective action and institutionalized endeavor ${ }^{15}$. In most cases, social capital has been understood in terms of its bonding functions in building collective action and in-group cohesion.

${ }^{13}$ FOURNIER, Francine., Which Role for Civil Society and the State?., UNESCO., 2002., 7.

${ }_{14}$ DARCY DE OLIVEIRA, Miguel., Citizen Participation and Social Capital Formation., UNESCO., 2002., 16.

${ }_{15}$ COLEMAN, James., Foundations of Social Theory., 1990. 
The primary importance of social capital has been to act as a bridge between political theory, economics and sociology, and between the analysis of market and non-market domains. Megan Alessandrini, a significant researcher of Social Capital refers to it as voluntary associations and organizations outside the market and state. This proliferation of private initiatives for the public good is profoundly reshaping the current patterns of relationships between the State and society. Citizen involvement and public-private partnerships do not constitute an alternative for the programs and policies implemented by the State, but rather a prerequisite for their implementation in a more efficient and equitable manner. Serving the public interest is not only the duty of the State, but also the permanent task and responsibility of all citizens.

The growing participation of citizens and their organizations in the public sphere is also a global phenomenon, coincident with the emergence of what various authors describe as a more reflexive and energetic - and less passive- society. This is because today, citizens are increasingly being called upon to produce value judgments and to make choices where, before, they had only to conform to a pre-established destiny ${ }^{16}$.

The emergence of the so-called network society, based on knowledge and innovation, and propelled forward by information and communication technologies, is facilitating the growing dialogue and interaction between groups and individuals and it is opening the way for new forms of social awareness, public debate and citizen involvement in all matters of public interest. In developing countries the money to build effective civil organizations may be scarce, but resources -skills, expertise, organizational capability and networks - are abundant. The challenge is how to organize and invest this social capital with efficiency and scale.

${ }^{16}$ GIDDENS, Anthony., The Consequences of Modernity., Stanford University Press., 1990. 
It is not enough to educate the poor. It is just as important to educate the non-poor to make them understand the restrictions that poverty puts on the day-to-day lives of the poor, to make them understand what it takes to open up society for better integrating the poor, and what tolerance and understanding it takes for them to open up their own personal networks for the creation of social capital among the poor ${ }^{17}$.

Given the above discussion, we could say that Human Capital Development is the greatest challenge a Global City has to face in order to compete in the global era. The government, civil organizations and citizens, must work together to provide a better and equal education system for all children. Therefore, in order to participate in the formation of the human capital debate, this research will focus on the potential human capital that exists on low socioeconomic children in Global Cities like Chicago, Mexico City and Paris, because of their importance to the future of the city. What are these cities doing in terms of providing equal access to quality education opportunities as the first step to create their human capital? Specifically, this study focuses on the public-private and grass roots organizations role in providing education opportunities to the children of immigrant and low socioeconomic status families.

\section{METHODOLOGY}

This research analyzes through a case study in Chicago, Mexico City and Paris: First, what is preventing the equal access to quality education opportunities in each of these cities? Second, what are some civil organizations that substitute the role of the government by providing education opportunities in Mexico City and Chicago? And third, in terms of promoting equal access to quality education, what should be the public and private roles to provide these opportunities in order to create the Human Capital of the Global City?

${ }^{17}$ FOURNIER, Francine., Which Role for Civil Society and the State?., UNESCO., 2002., 14. 
In order to answer these questions, this research will use primary sources such as government reports, conferences, articles, international rankings, speeches and interviews with experts and some organizations that are involved in the low socioeconomic and immigrant children development, politicians, philosophers and sociologists in Chicago, Mexico City and Paris.

\section{CASE STUDY: CHICAGO, MEXICO CITY AND PARIS}

\section{Chapter 1: Chicago}

\section{What is preventing equal access to quality education opportunities in Chicago?}

It is important to understand that Chicago's history has made it the center of national and international trade and that it has struggled to retain its economic and social viability in the face of globalization. But as The Federal-State Compact called «The Vital Center» reports, it is essential to remain competitive and to do so, the region faces several challenges, chief among them an underdeveloped human capital base, a weak culture of entrepreneurialism, largely uncompetitive metropolitan areas, and a legacy of employee benefit, job, and income security programs unsuited for today economy.

This report also argues that despite the large numbers of graduates the universities produce each year, the Great Lakes region continues to be hampered by serious human capital deficits, reflected in a population that generally lacks degrees essential to succeed in today economy. We can also point out from this report, that the stark racial and economic divisions have a terrible effect on those families left behind in neighborhoods with increasingly limited access to employment opportunities, quality schools, and basic goods and services. 
The main reason for the lack of equal education opportunities in Chicago is that there is no tax relationship between the city of Chicago and its suburbs, particularly in the realm of funding for public education. The main source of revenue for public schools is Property Tax. Areas with significantly higher tax rates and low property values are not able to develop good schools, which prevents them from attracting young, upwardly mobile families and the process becomes cyclical.

Because schools are funded primarily by property taxes, large fluctuations in property value and other nearby tax-generating developments can create vast inequalities in school funding, so municipalities without either already high property values or assets or some high-end commercial firm lack the ability to generate significant income for education on their own. The result is inadequate or grossly unequal municipal funding for public schools.

The opening of jails in Illinois has also prevented education funding to be sufficient and some children's perception is that the government is expecting them to be criminals instead of successful students. So, «We must match America's commitment to putting criminals in jail with the same commitment to preventing kids from becoming criminals in the first place» ${ }^{18}$. There are 40,000 criminals in jail in Illinois and that is costing too much money that should be provided to education opportunities.

Very much of the success of Chicago as a global city depends on its attracting skilled people, keeping them and letting them innovate, letting them lead the city forward. The region is doing fine, but the city itself seems more successful in attracting people than keeping them. As the Chicago Council on Global Affairs recommends, to build human capital is crucial and Chicago should educate region's people at all levels, enabling them to contribute to the economy of a global city and to make maximum use of the jobs opportunities.

${ }^{18}$ GREEN, Don., Deputy Chief of Knoxville Police Department. 
In 2003, the Federal Reserve Bank of Chicago sponsored a conference called «Strategies for improving the Midwest work force» where they mentioned that the Bank 1997 study assessing the turnaround in the Midwest economy found that regional work force development and education strategies would be critical to sustaining economic health. The study suggested that as physical capital played a less important role in economic growth, human capital would grow in importance as an economic input. Mayor Daley has made the improvement of public education in Chicago his leading priority. He believes that Chicago is in a global economy and that it can compete only if they give every child an opportunity. The dropout rate in Chicago city high schools (between 30\% and 40\%) is too high. In 2006, the Chicago Council on Global Affairs also published the book: «A Shared Future: The economic engagement of Greater Chicago and its Mexican Community» where they argue that like other immigrants before them, Mexicans come to Chicago in search of a better life for themselves and their families. They work hard so that their children can obtain a good education, pursue successful careers, and enjoy better lives than they did.

Mexican immigrants are a highly motivated and entrepreneurial workforce already making an enormous contribution to the economy of the region. They are $80 \%$ of the Chicago Latino community. Latinos represented almost $15 \%$ of the Illinois labor force in 2004, they are a young population and their bilingual and bicultural capabilities represent opportunities for business and cultural exchange with the 2.4 trillion market of the world 21 Spanish-speaking countries. Yet, the full integration of Mexican immigrants into the economic and civic life of the region is hampered by many problems, such as a lack of English proficiency, adjustment to American cultural norms, limited connections to the wider community, and low levels of education.

As employment in Chicago area continues shifting from manufacturing to service and technology, the increasing need for a highly trained, educated, multilingual workforce requires that the region offer highquality education from preschool through college for all its residents, including Mexicans. Mexican immigrants come to the U.S. with low 
levels of education and Mexican children have among the lowest levels of high school and college completion of all ethnic and racial groups in the region.

The Consortium of Chicago School Research at the University of Chicago reports that almost half of Latino students drop out of public high schools in Chicago, and those who do finish are less likely than other graduates in Illinois and the country to attend college. Further, school districts with high percentages of low-income and students of color are more likely to have teachers who are inexperienced and have lower basic academic skills.

\section{Are there civil organizations that substitute the role of the government by providing education opportunities?}

Equal education opportunities are prevented when a global city like Chicago gains rapid population growths (as the result of large immigrant flows) and the city does not have the infrastructure needed to provide education to all this citizens, especially children, and in addition to that, public funding for education comes from property taxes and in some neighborhoods is not enough. That is when civil organizations emerge to substitute the government's role to provide education to these children. In Chicago this research will analyze four examples of organizations that focus on the education of children of immigrant and low socioeconomic status families.

\section{a) Erie Neighborhood House}

Established in 1870 in the settlement house tradition, Erie House evolved into one of the first comprehensive social service agencies in Chicago and is now a recognized nonprofit leader. Erie's educational programs reach over 5,000 participants annually, providing a pathway to success and strengthening communities ${ }^{19}$. Erie Elementary Charter School is a

${ }^{19}$ [http://www.eriehouse.org/about.asp?objectTypeID=7\&objectID=188]. 
bi-literate K-5 school focusing on heritage and culture. It empowers Latino and diverse low-income communities to reach their fullest potential with a range of educational programs for all ages. Their mission is to promote a just and inclusive society by strengthening low-income, primarily Latino families through skill-building, access to critical resources, advocacy and collaborative action. One of their core values is to affirm the dignity and capacity of all persons to reach their fullest potential.

Erie provides bilingual/bicultural, developmentally appropriate care for more than 600 children annually from six weeks to 12 years old and it uses the developmentally appropriate practices approach and exercises a model of continuous improvement for children's specific needs and gifts, as well as staff's professional development. Children's physical, social, emotional and cognitive growth is developed through activities designed to foster language development, literacy, creativity, independence and school readiness ${ }^{20}$.

\section{b) Bethel New Life}

Bethel New Life advocates for West Side families to be heard by the school system as they work to develop quality schools of choice. Quality Education for All is one of their three strategic goals. They support educational initiatives that bring together parents, students, teachers, and the community. They work towards making the place a model of what can happen when people work together for the common good. They are community directed. Most of their board members are rooted in the community; Bethel functions through major participation of residents on Boards and committees and block clubs, participating churches, staff. They use an «asset based» approach, building on the strengths and capacities of the people and the place, starting with what they have, with what people know and want. Work for healthy families and child care, quality education, transportation and access to health care for sustainability. They work in partnership with churches, corporations, government, and other groups towards a healthier, sustainable community.

${ }^{20}[$ http://www.eriehouse.org/programs.asp?objectID=13]. 


\section{c) Voices for Illinois Children}

They work across all issue areas to improve the lives of children of all ages throughout our state so they grow up healthy, happy, safe, loved and well educated ${ }^{21}$. Their mission: «Voices for Illinois Children» champions the full development of every child in Illinois to assure the future wellbeing of everyone in the state. They work with families, communities and policymakers on all issues to help children grow up happy, healthy, nurtured, safe and well-educated ${ }^{22}$. It was established in 1987, by a group of civic, business, community, academic and philanthropic leaders to develop and promote strategies which improve conditions for all children throughout the state.

As a privately funded organization, Voices for Illinois Children seeks to educate opinion leaders and policymakers on all issues facing children and families. Over the years, Voices has grown into a powerful and wellrespected advocate, uniting community leaders and people who care passionately about children into a statewide network helping to establish new policies and implementing innovative programs to improve education, health care and family economics. For example, accomplishments in terms of education for children include ${ }^{23}$ : The Early Intervention program is created (1991). Also the Healthy Families Illinois (1994), a program that offers voluntary home visits to help new families learn how to have healthy relationships with their children. In 2003 The Children's Mental Health Act is approved and in 2006 Preschool for all is approved, making Illinois a national leader in its plans to provide voluntary, quality preschool to all 3 and 4-year-olds.

The Budget \& Tax Policy Initiative at Voices for Illinois Children provides information and analysis on spending and revenue topics that directly impact the lives of children and families. As part of the State Fiscal Analysis Initiative and the Economic Analysis and Research Network, Voices is broadening public participation in the debate over state fiscal priorities ${ }^{24}$.

${ }^{21}$ [http://www.voices4kids.org/].

${ }^{22}$ [http://www.voices4kids.org/aboutvoices/missionandhistory.html].

${ }^{23}$ [http://www.voices4kids.org/aboutvoices/missionandhistory.html].

${ }^{24}$ [http://www.voices4kids.org/issues/budgetandtaxpolicy.html]. 


\section{d) A+ Illinois}

It is a statewide campaign led by groups and individuals committed to real reform in the quality and funding of public education for all Illinois children. It seeks to improve the quality of life of children and their families through a comprehensive restructuring of state finances that balances property tax reform with new state revenues that fairly and adequately respond to community needs.

The A+Illinois Campaign declares that Illinois schools are in a financial quagmire: «They do not have enough money to provide the quality education that children deserve and laws require. In order to fill resource gaps, local property taxes - currently the principal funding stream for schools - have escalated. Such action has driven businesses out of the state and increased housing costs. The current system does not generate enough revenue for Illinois to pay its bills, leaving many families and communities in jeopardy. Whether measured in human or economic terms, not solving these problems now means we will later pay even more» ${ }^{25}$. This campaign stands for fare and adequate funding and high quality and accountable schools.

A+Illinois demands changes to make school funding more adequate and fair for all children and communities and supports proven strategies that build capacity to improve student learning and close the student achievement gap. It also aims to help develop and support comprehensive reforms that tackle the state's broken school funding and tax system, and put Illinois on better footing to protect the education, human services and community programs that are vital to the well-being of children and families.

Should civil organizations substitute the government's role in providing equal education opportunities? Do the education provided by charter schools is equal or better than in public schools? Are both providing children the required skills? Have charter schools better success stories

${ }^{25}$ [http://www.aplusillinois.org/aboutus/about.asp]. 
than public education programs? Do this success stories depend only on that or what about the student's background: family education, values, socioeconomic status and emotional intelligence? That should be further studied, but we can see that the efforts done by these organizations have achieved better results on education opportunities and policies in Chicago, as this study will explain.

\section{What should be the role of the government and the civil organizations, in order to improve together equal opportunities to high-quality education in Chicago?}

In order to build this human capital in a Global City developing all its potential, equal education opportunities must be promoted. The government, civil society, private business and citizens should work together with an integrated approach with concrete goals and strategies. Efforts should be done to reform school funding and improve education quality.

Today, it is hard to imagine any politician or business leader arguing against investment in human capital. "In the economy of the 21st century, knowledge, human capital, is the future...», the British prime minister, Tony Blair, declares. On the other side of the world, Australian opposition leader Kevin Rudd announces, «it is now time for a third wave of economic reform-a human capital revolution, an education revolution, a skills revolution» ${ }^{26}$.

Private business play a role on the human capital development because need to provide training to their workforce to keep them updated and competitive. On the other hand, citizens have the responsibility to commit to their communities, be responsible, take advantage of the jobs and opportunities that a global city can offer and contribute and participate in the economy.

${ }^{26}$ KEELEY, Brian., Human Capital: A revolution?., OECD., 2007. 
The government must make school funding more adequate and fair for all children and communities, so political will is crucial to this process. Quality reforms in education are an intrinsic piece of the overall school funding and tax reform discussion, helping to guide the effective use of public dollars efficiently and responsibly. They need not only to develop but retain human capital by providing a safe, attractive and livable city.

Civil organizations must keep working to help struggling students and schools to meet state learning standards, while preserving highquality education where it already exists. Support proven strategies that build capacity to improve student learning and close the student achievement gap.

One of the most important roles of Civil Organizations is to participate in policy making initiatives. For example, The Budget \& Tax Policy Initiative at Voices for Illinois Children provides information and analysis on spending and revenue topics that directly impact the lives of children and families. As part of the State Fiscal Analysis Initiative and the Economic Analysis and Research Network, Voices is broadening public participation in the debate over state fiscal priorities.

The government and civil organizations must support each other if they want to keep being competitive and to provide their people a better quality of life. In other words, people are not only what makes a community work (means), but are its final goal. Therefore decisions should be oriented to favor human beings.

The first step to create better policies for education is to form consensus. Civil organizations must get together with the government and work to promote policies that encourage equal and quality education opportunities by changing the financial formula to obtain more funding for public schools and upgrading the education quality in order to close the achievement gap between high and low socioeconomic status children and therefore start with the development of the potential human capital of Chicago. 


\section{a) Change the financial formula: Tax Reform}

School children across Illinois are living with bigger class sizes, old textbooks, crumbling buildings and cuts in core classes and extracurricular activities. That's because Illinois' method of funding education creates some of the worst inequities in the nation.

Illinois contributes a smaller share of school funding than the U.S. average ${ }^{27}$ :

Illinois

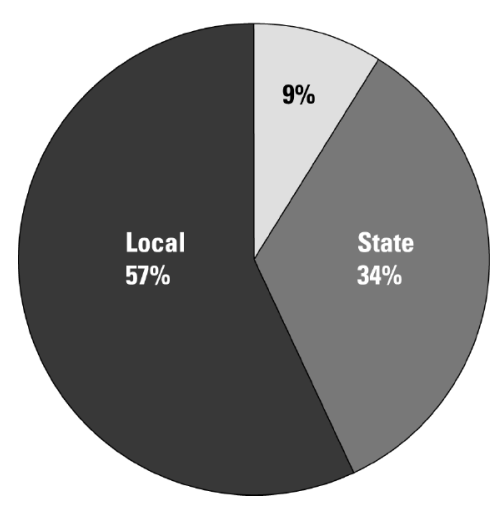

Illinois contributes a smaller share of school funding than neighboring states ${ }^{28}$ :

\section{U.S. Average}

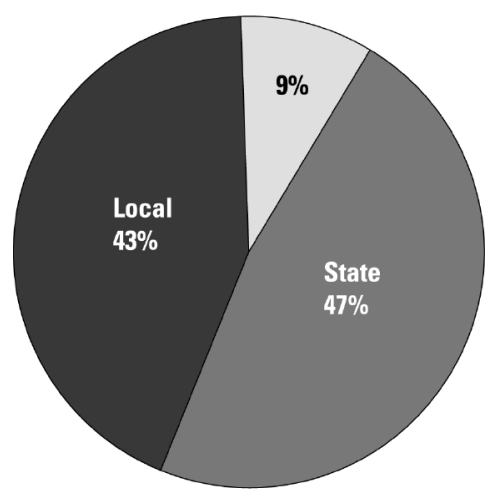

${ }^{27}$ U.S. Census of Governments, Public Education Finances., 2005.

${ }^{28}$ Idem. 


\section{Ilinois'Share of School Funding \\ v.s. Neighboring States}

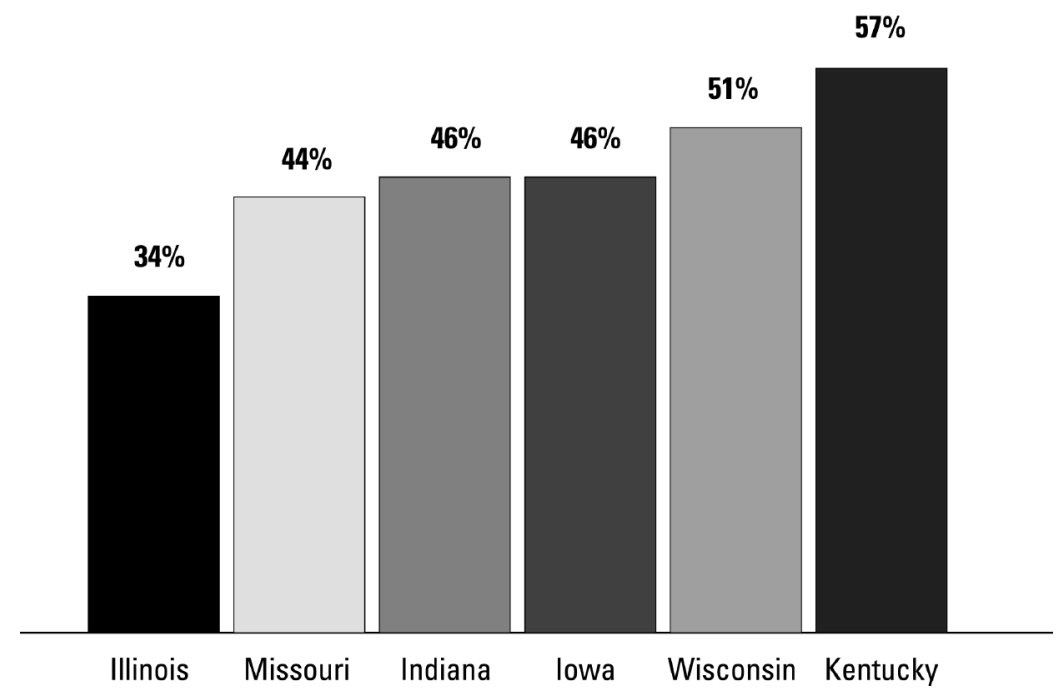

Illinois' tax structure is outdated and causes hardship for many families. Lower-income households pay a greater percentage of their income in state and local taxes than wealthier households. Also, the tax system doesn't raise enough revenue to adequately fund education, health care, human services and other critical supports children need to succeed. Illinois schools do not have enough money to provide the quality education that children deserve and a global city requires.

But speaking out and creating consensus makes a difference. Progress has been made in Illinois as the result of the civil organizations and the government working with synergy. For example, The Voices of Illinois Children Organization prepared a report to attract the government's attention to the education problems. As a result on March 7th of 2007, Governor Rod Blagojevich presented his FY 2008 state operating and 
capital budget proposals where health care and education are top priorities for the coming year. The Governor proposes nearly $\$ 1.5$ billion in new funding for PreK-12 education initiatives, an increase of more than $17 \%$. Programs receiving an increase in the proposal include General State Aid (19 percent), the Early Childhood Block Grant (22 percent) and special education (36 percent). The Governor also proposes a capital budget with a $\$ 1.2$ billion recommendation for education, including $\$ 500$ million for school construction and $\$ 10$ million for preschool capital projects ${ }^{29}$.

Still, it is not enough to increase the state funds, it is also very important to increase the local funding resources because their share represents $57 \%$ of the funds and many school districts do not have access to local property wealth to make up for the lack of state funding therefore the financial formula has to change, and this is what some advocacy groups in Chicago like Voices for Illinois Children are trying to promote with the A+ Illinois Campaign but there has to be political will to accomplish these goals.

\section{b) Upgrades in education quality: School Reform}

It would be important to mention that 10 to 12 years ago Richard Daley was the first mayor to take control of the management of public schools in order to improve them. In order to upgrade the public education system, he created the «Magnet Schools». It has not been measured if it has worked but the general perception is that it has indeed improved. Today he has been followed by some cities like Philadelphia and New York. But still 90\% of children in Chicago Public Schools (over 100) belong to low income families. Illinois has some of the nation's largest achievement gaps between low and high socioeconomic status children ${ }^{30}$.

In order to provide more equal opportunities and to improve the education quality required to develop the potential human capital of a city like Chicago, other measures must accompany the finance reform. For

${ }^{29}$ Maneesha Date., The Governor's FY2008 Budget Proposal., 2007.

${ }^{30}$ Education Trust., State NAEP Tables, Fall., 2006. 
example, the state and organizations need to point their efforts to promote: early childhood quality education, institute Accountability and Evaluation Reform (like the «No Child Left Behind» program), create Education Venture Pools and Broaden Charter School Options. Charter schools are helpful to provide equal education opportunities to all children regardless of their background because of the nature of their funding (public resources). So once the child is receiving education, the most important challenge is to encourage him to keep studying and go to the university. More than $12 \%$ of Illinois students do not graduate from high school and More than $27 \%$ do not meet Illinois Learning Standards ${ }^{31}$.

Some Charter Schools have realized that expectations and aspirations on the children have a huge impact on high school dropout rates and according to some organizations; expectations for the Illinois' children to grow up and go to the University are as low as their aspirations. That seems to be one of the most important issues that needs to be addressed by the teachers. The «No Child Left Behind» program changed the testing but not did not reform the teaching to be more effective and encouraging. But some efforts have been done, for example, The Erie Charter School tries to create aspirations by communicating the students their expectations on them to go to the University and reinforcing their aspirations.

Given all of the above discussion, this research could agree with the argument that: «In the new knowledge-based economies, more and more people are at risk of finding themselves thrown to the margins both of economic and social life because they lack training and retraining and, because of this, the ability and confidence to handle new realities» ${ }^{32}$. It is also important to consider that creativity and innovation, which are basic elements to keep the development and growth of the economy, are capabilities that when nurtured by education, allow people to give better results on their work (products, services, ideas) and that reflects on a better community.

${ }^{31}$ ILLINOIS STATE BOARD OF EDUCATION., Illinois State Report Card., 2006.

32 KEELEY, Brian., Human Capital: A revolution?., OECD., 2007. 
Equal opportunities to high-quality education must be recognized as both, a human right and a vital element a global city must offer as the first step to develop its potential human capital. Brian Keeley argues that «what you know shapes your life», but education is also what shapes the whole community. All the knowledge and skills you learn not only will let you to get a better job, but it will also have an impact on the way you work and give results that benefit all.

There is an urgent need for democratic macroeconomic controls that enable both reasonable economic growth and social development. Building human capacities and ensuring democratic and good governance constitute inseparable elements of the right to development. The benefits resulting from such growth should ultimately flow throughout the entire fabric of society, and spread to the very base of the social pyramid ${ }^{33}$.

\section{Chapter 2: Mexico City}

\section{What is preventing equal education opportunities in Mexico City?}

\section{a) Background: Education opportunities in Mexico City}

Mexico City has played a protagonist role throughout the country entire history and this situation has made the city the principal target for national immigration from the country side. Children in Mexico City living on the streets and $70 \%-80 \%$ of them are national immigrants ${ }^{34}$. Because of the political background of the country, the city has suffered serious economical setbacks, that in addition to the rapid growth of the population due to huge immigrant inflows and lack of urban planning, have generated infrastructure and managerial problems that have caused

${ }^{33}$ OURNIER, Francine., Which Role for Civil Society and the State?., UNESCO., 2002., $7,9$.

${ }^{34}$ LÓPEZ CÓRDOBA, Marco Antonio., Fundación para la Protección de la Niñez., 2007. 
the sprawling of vulnerable neighborhoods with increasing poverty, crime, low quality of life, children exploitation, pollution and a lack of housing, education opportunities and health services.

All this problems have prevented the city to develop a healthy and competent human capital able to participate in the economy and to impulse the development of the communities to help Mexico City to grow, improve and be competitive as a Global City.

In Mexico the Secretaría de Educación Pública (SEP) is in charge of providing education. Primary School (6-12 years old) and Secondary School (12-16 years old) are mandatory. People over 16 years old can finish the secondary school for workers or for adults. Only since 2004 pre-school is mandatory for all Mexican children. However, Population in Mexico City between 5 and 24 years old is 2,282,000 according to the official census in $2005^{35}$. From the 7,794,967 people over 5 years old that lives in Mexico City, around 360,000 cannot read and write and 202,809 have never been to school.

Mexico is a very complex city, it is trying to retain young people in school through a massive scholarship program.

Dropout rates in Mexico City according the National Institute of Statistical and Geographical Information are ${ }^{36}$ :

\begin{tabular}{|l|c|c|c|c|}
\hline $\begin{array}{c}\text { Distrito Federal } \\
\text { 2005-2006 }\end{array}$ & Primary & Secondary & $\begin{array}{c}\text { Technical } \\
\text { Professional }\end{array}$ & Highschool \\
\hline Men & $2.0 \%$ & $12.5 \%$ & $27.8 \%$ & $18.8 \%$ \\
\hline Women & $1.8 \%$ & $7.3 \%$ & $23.3 \%$ & $13.5 \%$ \\
\hline
\end{tabular}

${ }^{35}$ INEGI., II Conteo de Población y Vivienda 2005.

${ }^{36}$ INEGI., Índice de Deserción., November., 2007. 
These rates also correspond to the decreasing education offer in different levels which starts with 3,684 preschools and only about 550 schools offering higher education as the following table shows. These gaps in the system are often explained by lack of funding and other structural and organization problems in the SEP.

Education Resources in Mexico City for 2007. Schools and Teachers ${ }^{37}$ :

\begin{tabular}{|c|c|c|}
\hline Educational Level & Teachers & Schools \\
\hline Distrito Federal & 171387 & 9707 \\
\hline Preschool & 13953 & 3684 \\
\hline Elementary & 36065 & 3386 \\
\hline Secondary & 34554 & 1386 \\
\hline Profesional Technical Professional & 4057 & 98 \\
\hline Highschool & 28215 & 576 \\
\hline Superior Technician & 857 & 12 \\
\hline Normal Degree & 1205 & 35 \\
\hline University Bachelors ${ }^{a}$ & 44092 & 301 \\
\hline Posgraduate courses ${ }^{b}$ & 8389 & 229 \\
\hline
\end{tabular}

On August 15th, 2008 the National Ministry of Education (SEP) announced that for the first time, a national exam was applied to evaluate the professors throughout the country in order for them to apply for jobs. The results did nothing but to show the disaster of the situation that

${ }^{37}$ INEGI., II Conteo de Población y Vivienda., 2005. 
Mexico faces in terms of quality education. The results were that $68 \%$ of the teachers that presented the exam failed because they did not get the minimum of $70 \%$ that was required.

This proves the unfair situation that the children of this country (and others with the same problem) simply do not deserve. Even though this process and the transparency of the SEP in providing the results are a good start (compared to France, for example, where teachers refuse to be evaluated), it is unconceivable that the problem is that now that the SEP has this information and can do something about it and fast, there are not going to be any consequences for the professors that where already teaching, failed the exam and will not leave the classroom or be obliged to prepare themselves better.

Funding: 2007 Finance Report of Mexico City Expenses ${ }^{38}$.

From the total funding of $20,266,169,699$ to support programs in Mexico City only $7 \%$ was given to encourage the Development of Education and Sports $(\$ 1,526,164,676.00)$. Other investments (pesos) that encourage human capital formation in Mexico City were the following:

\begin{tabular}{|l|l|}
\hline $\begin{array}{l}\text { System for the Integral Development } \\
\text { of Families of the Federal District }\end{array}$ & $1,919,002,274.00$ \\
\hline Medium - High Education Institute & $507,643,505.00$ \\
\hline Federal District Youth Institute & $61,586,986.00$ \\
\hline Human Rights Commission & $242,172,486.00$ \\
\hline Universidad Autónoma de México (UNAM) & $705,173,946.00$ \\
\hline
\end{tabular}

${ }^{38}$ Secretaría de Finanzas, D.F. [http:/ / www.finanzas.df.gob.mx/egresos/2007/decretoEgresos2007.html]. 


\section{b) International Benchmarks}

Governments are paying increasing attention to international comparisons as they search for effective policies that enhance individuals' social and economic prospects, provide incentives for greater efficiency in schooling, and help to mobilize resources to meet rising demands ${ }^{39}$. This research will show Mexico City position within some international indicators related to human capital development and the education in order to analyze the situation of Mexico City.

The Program for International Student Assessment (PISA) is an internationally standardized assessment of scientific, reading and mathematical literacy that was jointly developed by the OECD and participating countries, it is administered to 15-year-olds in schools. The survey was implemented in in the 1st assessment in 2000 and now 62 countries have signed up to participate in the 4 th assessment in $2009{ }^{40}$. This survey of the knowledge and skills of 15-year-olds shows that some countries have seen significant improvements in student performance since 2000. This study also proves that Mexico as well as Greece has had a significant improvement in mathematics performance between 2003 and $2006{ }^{41}$.

Private vs. public involvement in the operation and funding of schools is important to the education system in Mexico City. In the PISA school background questionnaire, principals of tested schools report whether their school is a private school, which is managed directly or indirectly by a non-government organization (church, trade union, business, or other private institution), or a public school, which is managed directly or indirectly by a public education authority, government agency, or governing board appointed by government or elected by public franchise. While the share of government funding lies below 60 percent on average in Korea, Mexico, and Turkey, many

${ }^{39}$ Education at a Glance 2007-Briefing note MexicoOECD., 2007.

${ }^{40}$ [http:/ / www.oecd.org/document/22/0,3343,en_2649_37455_39713238_1_1_1_37455,00.html]. 04-12-2007.

${ }^{41}$ OECD., PISA 2006 Science Competencies for Tomorrow's World., 2007. 
countries such as Finland, Germany, Iceland, Luxembourg, the Netherlands, Norway, Poland, Sweden, and Switzerland have an average share of government funding above 95 percent ${ }^{42}$.

The survey also revealed widespread pessimism among secondary school students about environmental challenges and limited enthusiasm for scientific careers. Students from families with a more advantaged socio-economic background were more likely to show a general interest in science. In Australia, Canada, Finland, Japan and New Zealand, at least $14 \%$ students reached the top two levels of scientific literacy. In Greece, Italy, Mexico, Portugal, Spain and Turkey, by contrast, the proportion was lower than $5 \%$.

On average across the OECD, students in private schools outperformed students in public schools in most countries. Creating scientific interest in citizens is important for Mexico City to take in consideration, because of the impact of environmental problems in the quality of life and the need to encourage scientific research and innovation, which are very important aspects to develop the human capital formation process.

According to the World Economic Forum Global Competitiveness Report ${ }^{43}$, The United States tops the overall ranking. Switzerland is in second position followed by Denmark, Sweden, Germany, Finland and Singapore, respectively. The survey includes more than 100 variables and was done in 131 countries which represent more than $98 \%$ of the World GDP. Mexico occupies the 52nd position in this ranking.

Other benchmarks this research will take in consideration to analyze the environment on which human capital is developing in Mexico City are:

Knowledge creation and information flows ${ }^{44}$

Variables: number of universities, number of MBA's, Medicine Schools, Forms for patent registers, Google hits, Research per inhabitants,

42 Idem.

${ }^{43}$ WORLD ECONOMIC FORUM., The Global Competitiveness Report 2007-2008., 2007.

44 «Top 50 cities»., MasterCard., 2007. 
Articles in technical and scientific magazines, Number of papers, access to Internet. In this subject Vancouver occupies the first place, followed by Toronto while Mexico City is in the 45th place of the ranking.

\section{Health and Salubriousness ${ }^{45}$}

If infectious diseases, medical and hospital sources, air pollution levels, waste management, water management and presence of harmful animals are taking in consideration as variables, the rakings show that Calgary, Helsinki and Honolulu are in the top of the ranking, respectively, as the best cities to live in terms of health, while Mexico City is in the 211th position.

Quality of life ${ }^{46}$

Zurich, Geneva and Vancouver are respectively the tree cities with better quality of life if the following aspects are taken in consideration: social and political environment, economic environment, health, education, public services and transport, recreation, consumer products, housing, environment. While Monterrey is in 94th place, Mexico City occupies the 128th position.

Wealth and salaries ${ }^{47}$

Taking the salary index in consideration, it could be said that while Zurich, Geneva and Oslo are the three cities with more wealth, Mexico City is on the 63rd position.

\section{c) Public or Private Education Debate}

As above mentioned, Mexico is one of the countries in which less than $60 \%$ of the education funding comes from the government and that it should take more responsibility, but on the other hand, there is a PISA study and argument that proves that accountability, autonomy, and choice

${ }^{45}$ Mercer Human Resource Consulting. 215 cities., 2007.

46 Idem.

${ }^{47}$ «70 cities»., City Majors., 2006. 
play a leading role in recent school reforms in many countries ${ }^{48}$. And it argues that different facets of accountability, autonomy, and choice are strongly associated with the level of student achievement across countries.

This research will now show and analyze the student achievement and long-run economic growth among the OECD countries from PISA 2003. Figures are based on a regression of the average annual rate of growth (in percent) of real GDP per capita in 1960-2000 on the initial level of real GDP per capita in 1960, average years of schooling in 1960, and average test scores on several international student achievement tests.

\section{Student Achievement and Long-Run Economic Growth ${ }^{49}$ \\ OECD-COUNTRY SAMPLE}

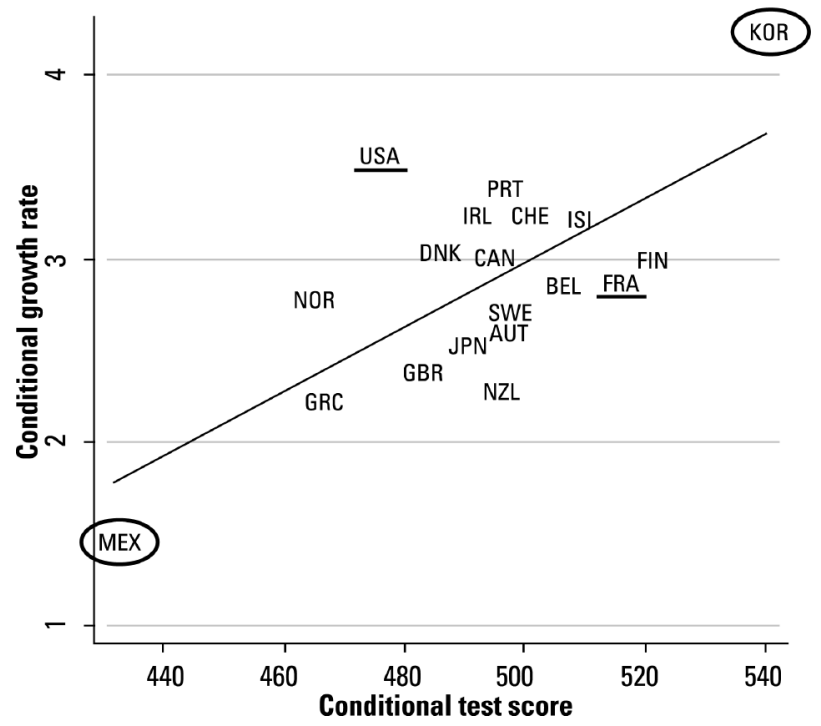

${ }^{48}$ LÜDEMANN, SCHÜTZ, WEST., School Accountability, Autonomy, Choice and the Level of Student Achievement: International Evidence from PISA 2003., OECD., September., 2007.

49 WÖßMANN, LÜDEMANN, SCHÜTZ, WEST., School Accountability, Autonomy, Choice and the Level of Student Achievement: International Evidence from PISA 2003., OECD., September., 2007. 
Among the OECD countries, Mexico and Turkey stand out by having an average socio-economic status that is a full standard deviation below the OECD average (as measured by the PISA index of Economic, Social and Cultural Status, ESCS; they also have by far the lowest GDP per capita).

According to the mentioned study, students perform better in countries with more choice and competition as measured by the share of privately managed schools, the share of total school funding from government sources, and the equality of government funding between public and private schools. While the relative lack of accountability, autonomy, and choice in the compulsory education sector as currently constituted tends to dull incentives to improve quality and restrain costs, marketoriented models may create incentives that ultimately lead to better student learning.

All over the world, nations tend to finance and manage the great majority of their schools publicly. According to the PISA 2003 study, unfortunately, the dominance of the public sector in education often limits incentives to improve student achievement while controlling costs. In the private business sector, market competition tends to encourage firms to operate efficiently so as to generate profits.

Inefficiency leads to higher costs and higher prices, which allows competitors to lure away customers. By contrast, a lack of competition and choice in most state-run school systems often creates obstacles to leaving bad schools, thereby constraining the ability of parents to ensure highquality education. Centralized bureaucracies often allow little flexibility at the school level, limiting schools' ability to respond to parental demands.

Understanding the sources of international variation in student achievement levels is an important project, because international differences in student achievement are a key driver of differences in long-run economic growth rates. Economic theory suggests that strong education systems will increase the long-run rate of economic growth because education is an investment in human capital that increases labor productivity and 
because it is a leading input for innovation and technical progress which in turn influence growth rates.

\section{2) Are there civil organizations that substitute the role of the government by providing education opportunities?}

The Mesoamerican cultures gave an important value to children within their family structure, considering them as beings of high esteem that inspired respect and care. They had a protection system and help to the unprivileged children. The Spanish conquest brought significant cultural changes where religious people were in charge of the underclass, unprotected children and they were taken care of and educated with a religious orientation. There were houses where they provided assistance, food and education, the first one was founded in 1865 by the Emperatriz Carlota. Because of the historical background it can be said that social assistance and initial education for unprivileged children have the same origin because both are implicit in the activities ${ }^{50}$.

In 1929 the National Association of Childhood Protection was founded and it is the origin of the formal current National System for the Integral Development of the Family (DIF).

At the same time ten "Children Homes» were created and then the Health Ministry established daycare facilities for the workers' children. In 1962 policies give the Mexican Institute of Social Security (IMSS) the task to provide daycare centers. The increasing demand, different criteria and services, and lack of an institution that controlled the organization and operation of all day care centers created the current Sub Ministry of Basic Education as a part of the Education Ministry. There are also Social Provision Houses that take care of the unprivileged children on the city.

${ }^{50}$ Revisión de las Políticas de Educación y Cuidado de la Infancia Temprana., SEP/OECD., 2003. 
All the efforts before mentioned have been government initiatives, but also along with this process civil organizations have emerged at the same time to fulfill the gap on the lack of resources and services for the unprivileged children. Today there are $162{ }^{51}$. Non Profit Registered Organizations in Mexico City that work with children and adolescent problems; 88 of them are dedicated to provide education opportunities in Mexico City. The most important are: San Ignacio de Loyola Vizcaínas, Fundación Becar, Fundación Social Anáhuac, Red de Estancias y Preescolares Populares, Colegio Luz Saviñón.

According to some philanthropic associations that work with underclass children in the city, there are about 14,000 street children out of the 26million inhabitants Mexico City, which represents $.005 \%$ but on the other hand the Social Development Institute of Mexico City declares a 1,800 street census children. This shows that there is not official and trustworthy data about social problems that hinder the human capital formation and development, and therefore actions to be taken cannot effective. The structural problem is poverty which deteriorates families and children; they grow up in the street without opportunities of development including education.

Civil Organizations such as the Fundación Para la Protección de la Niñez, coordinate and help each other to bring these children «from the streets to life». In 2008 the Government of the City passed a law, against the society and philanthropic organizations recommendations, in which street children were going to be taken care by the government. The main problem on the Government-Civil Organizations relationship is a lack of communication, coordination, understanding and support between them.

${ }^{51}$ Directorio de Instituciones de Asistencia Privada., JAP del D.F., 2007., p. 1-8. 


\section{3) What should be the role of the government and the civil organizations, in order to improve together the equal opportunities to access high-quality education in Mexico City?}

Mexico is a developing country that needs Foreign Investment in order to compete in this global world and converge with the first world countries. A high level of human capital is no doubt one of the key ingredients for attracting FDI, as well as for host countries to gain maximum benefits from their activities. Most developing countries, however, under invest in human capital, and the investment that is actually taking place is unevenly distributed across countries and regions that have adopted different human resource development (HRD) policies ${ }^{52}$.

In countries that lack well-developed capital and education markets, many otherwise qualified citizens may be denied the basic skills they need in order to contribute fully to the nation's economic development. As societies become divided, they become more conflicted, and this conflict hinders growth ${ }^{53}$. We are transforming to the «Rich and Poor Era» to the "Qualified and Disqualified Era» ${ }^{54}$. This is why it is so important to invest on human capital.

In order to improve the quality education opportunities in Mexico City it is necessary to, first, improve the public education system and quality to close the achievement gap between public and private schools in order to meet the international standards on education and human rights. And second, create the political and social conditions that would allow to found an institution dedicated to be an intermediary between the government and public organizations in order to create consensus and synergy to be more effective in solving the problems that are blocking the formation of a competitive human capital formation in the city such as: children

${ }^{52}$ Human Capital Formation and FDI., OECD., 2007.

53 KAPSTEIN, Ethan B., Virtuous Circles? Human Capital Formation, Economic Development and the Multinational Enterprise., OECD., 2002., p. 8.

${ }^{54}$ LLANO, Carlos., Interview., February., 2007. 
exploitation, street children, alimentary poverty, housing, encouraging sports and cultural activities

\section{a) The Role of the Government}

The SEP purpose needs to be creating conditions that assure the access of all citizens to a quality education in all levels. SEP vision for 2025 is that México will have a broad educative system that will offer education for the integral development of its population and that the system will be recognized internationally for its quality and constitutes the fundamental ax for the cultural, scientific, technological, economical and social development.

According to the OECD's Economic Survey on 2005, Mexico's performance has improved, but main economic challenges remain for education, labor markets, electricity and other network industries, ways of doing business, the medium-term fiscal framework and fiscal relations between levels of government. In their 2007 survey the OECD concludes that the past reforms to liberalize the economy have paid off. Mexico's per capita has increased and broad macroeconomic stability has been achieved. Furthermore, living standards remain well below those in other OECD countries, and current GDP growth is still not high enough to ensure rapid convergence.

It is important to mention that the Situation of Formal Commerce against Informal Commerce in Mexico City and how it affects the social and economical development of the human capital of the city. The illegal street activities and informal commerce have reached alarming dimensions. Studies made by the Mexico City National Chamber of Commerce since 1987, show that street vendors have grown incessantly. Informal Commerce that locates in the main streets and avenues of this city, in a semi-portable way, is not an alternative to solving the problem of unemployment. This kind of commerce is being held by families including the children that start working on the streets very young and most of the times, dropping out school. 
The government cannot offer this future of illegality to the new generations, falling in the trap of justifying the street vending as a effect of unemployment and the economic crises by which we have crossed. Legally established commerce is considered one of the most important productive sectors of the economy in the country, mainly for its participation in GDP, for its high contribution in federal taxation, for its generation of employment and for its direct services to the population.

The government of the City recognizes that it needs to develop their human capital and offer more job opportunities. A very important project to develop «Knowledge parks» within the city in order to attract specialized industries and headquarters are being planned, but it is important not to forget that the physical development of this project needs to be accompanied by the development of Mexican citizens that can take advantage of these global city jobs.

In 2008 the government of Mexico City is providing a massive program for scholarships, that tries to encourage the education in its young population, but there has to be a strong political leadership in the city that supports and encourages investment and development, security, education and job opportunities and quality of life in general. The program provided 6.1 million scholarships for students of basic, middle and higher education in the 2005-2006 period. The SEP increased the salaries for the teachers in public schools for 2008, but a quality reform has not accompanied this measures. Public schools should be competitive to be worthy of funding.

The government needs to be aware that the acquisition, development and retaining of human resources skills is essential to ensure high standards of quality, productivity and safety and should also support efforts related to international standards on education quality and improve processes in order to be competitive.

\section{b) Role of Civil Organizations}

The experience of Comunidad Solidaria demonstrates that in a country like Brazil money may be scarce, but resources — understood as 
skills, expertise, organizational capability and networks- are abundant. The challenge is how to mobilize and invest this social capital with efficiency and scale. In Mexico City there are many Civil Organizations willing to help the unprivileged children in the city, contributing to the development of the people and the society, therefore, there is plenty of expertise and advice that these organizations can provide to the government in order to make the efforts more effective.

Low-socioeconomic level children must stop being seen as a problem, but as an opportunity to increase the community's welfare. Mexico City needs to start investing in Human Capital Development if it really wants to be competitive and attract investment, but it is important to explain that people are not the means to get the «final goal» which is more money, but the human capital development increases the productivity and wellbeing of the community which is built for the people.

Since 1990's issues related to social and human development have been important to Mexico in order to meet international standards to be competitive and safe to attract Foreign Direct Investments. One of the most important decisions was to signs the UN's treaty to protect Children's Rights There is one organization in Mexico that has accomplished the objective of influencing social policy making and it is the Net for the Rights of Children in Mexico was founded 7 years ago, it is formed by 80 organizations, has a Technical Board and an Operative Staff. They have been able to positively influence the law, they research and provide indicators about the status of childhood problems in Mexico and they have an agreement with INEGI to obtain official information and write comparative reports with USA and Canada.

There is a huge industry behind philanthropy in Mexico and there are many wealthy entrepreneurs donating for the causes they believe in, so problem is not money is how we make ourselves co-responsible, proactive and productive. Creating communication and synergy to make these efforts more effective and go from «help for some» to «help for all». There is a big potential human capital in Mexico City waiting to be seen as an opportunity. It is important to mention that 
this research stands not only for the coordination and proactively between government and civil organizations, but also participation from the ones being helped to return what they have received when they are able to produce it, that way the society will be creating grateful and generous citizens instead of demanding ones.

As we have seen there are many efforts from the government, civil organizations and the philanthropies trying to help the unprivileged children in Mexico City get education opportunities and develop themselves. But, there is no coordination, communication, feedback or synergy among them, which makes progress less effective.

An organization capable of creating a space or project in which the expertise, power and will can influence the legislation in favor of equal quality education and development opportunities for all citizens in Mexico City. That way instead of isolated efforts that help a few children, policy making based on the civil organizations' experience and recommendations, can help all children.

The challenge would be to overcome the deep and structural problem that Mexico City faces, which is that as a society we do not know how to establish objectives to the government and measure the results, government does that by itself, and this happens because society (civil organizations and citizens) does not like to be demanded either.

Government should be responsible of providing official and trustworthy data and there should be an organization capable of creating not only proposals based on the experience of civil organizations that deal with this problems, but also demanding results from the government and measuring them, publishing the results for the citizens. There are 4 characteristics that block the participation of the citizens in orienting the government, all present in Mexico City's society: Ideological Dualism, Corporativism, Anomy and Tendency to the concentration of power ${ }^{55}$.

${ }_{55}$ NINO, Carlos Santiago., Radical Evil on Trial., NewHaven, Connecticut., Yale University Press., 1996. 
There is a big philanthropic industry around social problems in Mexico and the civil organizations objectives are not necessarily the same as the government plans. The socio-political interests in Mexico City are very complex and it would be necessary to build the political and legal conditions that allowed to create an organization that offers to create consensus between philanthropic organizations and government interests in order to establish measurable objectives to the government and therefore increase growth and competitiveness rates in a more effective way, making sure a human capital formation is a priority for everyone to assure Mexico City place in the competitive global world and transform it in a world class, global city.

\section{Chapter 3: PARIS}

\section{What is Preventing Equal Access to Quality Education Opportunities in Paris?}

In order to make this research a comparable and complete analysis, this case study takes Paris in this chapter as an example of the opposite case of Mexico City in terms of the public-private role in providing quality education opportunities. French education system is highly centralized, therefore, in Paris the participation of the government in providing education is above $86 \%{ }^{56}$, which means that the State almost completely controls this service, while in Mexico City most of the population that receives access to quality education and presents lower drop-out rates, come from private education or civil organizations. In this case study, Chicago would be in the middle position with a synergic interaction between the government and the private and civil organizations to provide education opportunities.

\section{a) Background: Education opportunities in Paris}

As most rankings that evaluate Global Cities demonstrate, Paris is today one of the world's leading business and cultural centers. It has a

${ }^{56}$ La Préfecture de la Region d'Ile de France., 2007. 
great influence in politics, research and development entertaiment, dedia fashion, science and arts makes it one of the world's major global cities ${ }^{57}$. The Paris Region (Île-de-France) is Europe's biggest city economy, and is fifth in the World's list of cities by GDP and it hosts 36 of the Fortune Global 500 companies ${ }^{58}$ in several business districts such as, the largest purpose-built business district in Europe ${ }^{59}$. Paris also hosts many international organizations such as UNESCO and the OECD and is also the most popular tourist destination in the world, with over 30 million foreign visitors per year ${ }^{60}$.

French education system has been used as a model that many countries have been trying to implement and many researchers have been studying its evolution through history. In the PISA rankings we can often find that education in France qualifies in the average among the OECD's countries. Education in France is provided to every child, is mandatory, free and well organized and managed by the State, but there are still many problems to be solved in the Paris Region such as achievement gaps demonstrated in different schools in the region due to the inequalities created by the system itself, the unemployment rate for young people finishing their studies is high and there is a debate rising about how the highly centralized education systems can be preventing that the competition among schools improve the education quality.

This chapter will frame the context of Paris' Human Capital Development starting with the background of the French education system and key data of Paris in terms of access to quality education opportunities.

${ }^{57}$ Inventory of World Cities., Globalization and World Cities (GaWC). Loughborough Univerity., 2007.

58 «Global Fortune 500 by countries: France»., Fortune., 2007.

${ }_{59}$ Logistics-in-Europe.com, Vertical Mail. «Paris Île-de-France, a head start in Europe»., Retrieved on 2007-10-04.

${ }^{60}$ INSTITUT NATIONAL DE LA STATISTIQUE ET DES ÉTUDES ÉCONOMIQUES., Le tourisme seporte mieux en 2004 (PDF)., 2007. 


\section{b) What is the role of the government in providing equal education opportunities?}

In order to better understand the role of the government and its importance in the highly centralized French educational system this study will analyze the history, basic principles, organization, system and problems of the French Education, specifically in Paris.

Just like we saw in the case of Mexico City, education in Paris started as a responsibility of religious institutions. In the early ninth century, the emperor mandated all churches to give lessons in reading, writing and basic arithmetic to their parishes, and cathedrals to give a higher education in the finer arts of language, physics, music and theology . Paris was already one of France's major cathedral towns and began its rise to fame as a education center. The Île de la Cité Notre-Dame cathedral school had many famous teachers by the early 13th century, so the Latin Quartier became the most important Paris' education center best represented by the Sorbone University.

The modern era of French education (l'École Républicaine) starts when Jules Ferry, a lawyer holding the office of Minister of Public Instruction in the 1880s required all children under the age of 15 to attend to school. He also made public instruction free of charge and secular (laïque). The French education system is based in five principles inspired after the French Revolution in 1789 and the laws between 1881 and 1889 and from the 1958 Constitution, and these principles are: La liberté de l'enseignement, La gratuité, La neutralité, La laïcité, L'obligation scolaire.

Today The Programme for International Student Assessment, coordinated by the OECD, currently ranks France's education as the 25th best in the world, being neither significantly higher nor lower than the OECD average ${ }^{61}$.

There have been two important décentralisation processes first in 1982 and second in 2003. French territory is divided into 35 académies. The main responsibility of the académie is to manage personnel and state

${ }^{61}$ [http:/ / www.oecd.org/dataoecd/42/8/39700724.pdf]. 
budgets pertaining to the education system. It serves as a link between regional specificities and the centralised governing body in Paris.

As this study mentions before, the French educational system is highly centralized and organized. It composed by three different stages: primary education (enseignement primaire); secondary education (enseignement secondaire) and higher education (enseignement supérieur). Schooling in France is required and mandatory as of age 6, the first year of primary school. Primary and Secondary education is predominantly public (private schools also exist, in particular a strong nationwide network of primary and secondary Catholic education), while Higher education has both public and private elements.

We can see that in Paris, there are not any organizations that help provide education opportunities because the government covers the need of equal access to education. So, this study will analyze what are Paris' achievements in terms of a high skilled workforce creation through comparing it with other global cities, specially Chicago in order to measure the effectiveness of a system where the government is offering $86 \%$ of the education opportunities, leaving out the competition of private and civil organizations to improve the quality in the education provided.

\section{c) Education Resources in Paris}

The city of Paris within its administrative limits has an estimated population of 2,167,994 ${ }^{62}$. The Paris unité urbaine (urban area) extends well beyond the administrative city limits and has an estimated population of 9.93 million in $2005^{63}$. The Paris aire urbaine (or metropolitan area) has a population of nearly 12 million $^{64}$, and is one of the most populated metropolitan areas in Europe ${ }^{65}$.

${ }^{62}$ INSTITUT NATIONAL DE LA STATISTIQUE ET DES ÉTUDES ÉCONOMIQUES (INSEE)., Estimation de population par département, sexe et grande classe d'âgeAnnées 1990 à 2006., 2008

${ }^{63}$ INSEE., Population des villes et unités urbaines de +de 1 million d'habitants de l'Union Européenne., 2006

${ }^{64}$ INSEE., Aire Urbaine '99 pop totale par sexe et âge., 2006

${ }_{65}$ HELDERS, Stefan., «World Metropolitan Areas»., World Gazetteer., 2007. 
As of the academic year 2004-2005, the Paris Region's 17 public universities, with its 359,749 registered students ${ }^{66}$, is the largest concentration of university students in Europe ${ }^{67}$. The Paris Region's prestigious Grandes Écoles and scores of university-independent private and public schools have an additional 240,778 registered students, that together with the university population creates a grand total of 600,527 students in higher education that year. In the next table we can see the Public and Private Education in Paris ${ }^{68}$ according to the data of the Préfecture de la Region d'Ile de France.

According to the Paris Academy ${ }^{69}$ primary education is provided by 772 schools (659 public and 113 private), 172463 students and 393,5 million Euros are invested. For Secondary education there are 375 school establishments, 159136 students and the total budget is 1066,6 million Euros. There are also 323861 students in higher education.

\begin{tabular}{|l|c|l|l|}
\hline $\begin{array}{l}\text { Primary } \\
\text { Education }\end{array}$ & Public & Private & Total \\
\hline Schools & 659 & 113 & 772 \\
\hline Students & 136304 & 36159 & 172463 \\
\hline Teachers & 7969 & 1447 & 9416 \\
\hline $\begin{array}{l}\text { Secondary } \\
\text { Education }\end{array}$ & Public & Private & Total \\
\hline Schools & 237 & 138 & 375 \\
\hline Students & 107058 & 52078 & 159136 \\
\hline Teachers & 12843 & 4042 & 16885 \\
\hline
\end{tabular}

${ }^{66}$ Regional Chamber of Commerce and Industry, Paris-île-de-France (2006)., Paris Region: key figures., 2006.

67 ROZENBLAT, Céline \& CICILLE, Patricia., Les villes européennes-Analyse comparative., Delegation for Spatial Planning and Regional Action., Datar., 2006., p. 46.

${ }^{68}$ La Préfecture de la Region d'Ile de France., [http://www.idf.pref.gouv.fr/donnees/ enseignement.htm].

${ }_{69}$ Academie de Paris., [http://www.ac-paris.fr/portail/jcms/piapp1_12549/ quelques-chiffres-sur-l-academie?cid=piapp1_6619]., 2008. 


\section{d) International Benchmarks}

Because of the point mentioned before in this study of how a highly educated pool of qualified and talented individuals is essential to the staffing needs of companies doing business in the city and to business's ability to drive innovation and to impact the quality of life by supporting cultural institutions and the arts. The «Cities of Opportunity» Study by Price Water House Coopers in 2007 analyzes Paris and Chicago position in ranking their intellectual capital. The other Global Cities included in this comparison were Atlanta, Frankfurt, London, Los Angeles, New York, Shanghai, Singapore, Tokyo, and Toronto.

\section{Intellectual Capital ${ }^{70}$}

Variables taken in consideration to measure the intellectual capital were: Top 500 universities, population with higher education and number of Nobel Prize winners.

London is first in the ranking while Paris is in second place followed by Tokyo and New York and Chicago occupies the 8th Place. In Paris there are 17 universities and internationally-renowed engineering and business «Grandes Écoles». The Wall Street Journal 2005 international ranking rates 2 MBA programs in Paris Region among the world's top 11.

\begin{tabular}{|c|l|c|c|c|c|}
\hline Rank & City & Score & $\begin{array}{c}\text { Top 500 } \\
\text { universities }\end{array}$ & $\begin{array}{c}\text { Population with } \\
\text { higher education }\end{array}$ & $\begin{array}{c}\text { Nobel Prize } \\
\text { winners }\end{array}$ \\
\hline 1 & London & 23 & $\mathbf{1 1}$ & 9 & 3 \\
\hline 2 & Paris & 22 & 10 & $\mathbf{1 1}$ & 1 \\
\hline 3 & Tokyo & 19 & 10 & 7 & 2 \\
\hline 4 & New York & 18 & 10 & 4 & 4 \\
\hline 8 & Chicago & 11 & 7 & 3 & 1 \\
\hline
\end{tabular}

${ }^{70}$ Price Water House Coopers. Cities of opportunities. 2007., p. 10. 


\section{Technology IQ and innovation ${ }^{71}$}

According to this study this indicator is one of the most important to evaluate the human capital a global city holds, because from corporate strategy to workforce issues, to public policy, to lifestyle, technology and innovation are and will continue to be the primary drivers of change. The variables taken in consideration for this indicator were: Internet users on broadband, High-tech services employment, Self employment and Patents. Paris takes the 3rd place in the ranking after Tokyo and London, while Chicago is in the 9th position.

We can see on the next table that Paris is the 7th city with more Internet users whereas Chicago is in number 8. In terms of patents registration, Chicago occupies the 5th place in whereas Paris is number 8th even though gross domestic expenditure on R\&D places Paris Region well ahead other European Regions. The Paris region hosts many international researchers and the number of scientific publications puts the region second in Europe, after London.

\begin{tabular}{|c|l|c|c|c|c|c|}
\hline Rank & City & Score & $\begin{array}{c}\text { Internet } \\
\text { users on } \\
\text { broadband }\end{array}$ & $\begin{array}{c}\text { High tech services } \\
\text { employment }\end{array}$ & $\begin{array}{c}\text { Self- } \\
\text { employment }\end{array}$ & Patents \\
\hline 1 & Tokyo & 35 & 7 & 11 & 6 & 11 \\
\hline 2 & London & 30 & 9 & 9 & 11 & 1 \\
\hline 3 & Paris & 29 & 5 & 10 & 10 & 4 \\
\hline 9 & Chicago & 17 & 4 & 5 & 1 & 7 \\
\hline
\end{tabular}

\section{Demographic advantages ${ }^{72}$}

Analyzing demographics advantages in cities such as Paris and Chicago is important because the growth of the already well developed

${ }^{71}$ Cities of opportunities., Price Water House Coopers., 2007., p. 12.

${ }^{72}$ Ibidem., p. 13. 
global cities almost depends on the right mix of people that provides advantages in terms of efficiencies, diversity, and depth of talent and skills available within the workforce. In examining demographics the variables taken in consideration by the "Cities of Opportunities» study were: Population density, Working-age population and Diversity.

\begin{tabular}{|c|l|c|c|c|c|}
\hline Rank & City & Score & $\begin{array}{c}\text { Population } \\
\text { density }\end{array}$ & $\begin{array}{c}\text { Working- age } \\
\text { population }\end{array}$ & Diversity \\
\hline 1 & New York & 23 & 10 & 2 & 11 \\
\hline 2 & Los Angeles & 21 & 6 & 9 & 6 \\
\hline 3 & Singapore & 20 & 8 & 10 & 2 \\
\hline 4 & Tokyo & 19 & 7 & 8 & 4 \\
\hline 5 & Chicago & 17 & 9 & 1 & 7 \\
\hline 9 & Paris & 16 & 11 & 4 & 1 \\
\hline
\end{tabular}

The table places this time Chicago with a better position than Paris. Paris takes the first place in the ranking in terms of population density, whereas Chicago is holding the 3th position. In terms of working-age population it is important to realize that Chicago and Paris are both in low positions. We also can see that Paris is the last city in the variable of diversity, while Chicago is in the 5th place, sharing it with Toronto and London.

About Diversity in Paris Region it can be said that after it is the 2nd most cosmopolitan region in Europe. It hosts around 724000 international workers and 64500 foreign managers of more than 100 nationalities predominantly form OECD countries ${ }^{73} .43 \%$ of international postgraduate students in France are in Île de France. The managers of major European

73 PARIS REGION ECONOMIC DEVELOPMENT AGENCY., The attractiveness of Paris Region., 2006., p. 22-23. 
companies consider that the Paris region attracts the best talent in Europe after London ${ }^{74}$. According to the Paris Region Economic Development Agency, in the «Attractiveness of Paris Region» publication in 2006, Paris Region attracts the very best French and overseas students ${ }^{75}$.

Paris is considered the biggest European student centre, with internationally renowned universities and engineering and management "Grandes Écoles». More than 25\% of the French student population is in Paris Region and more than 33\% of the national postgraduate population. International students account for $20 \%$ of postgraduate students in Paris Region.

\section{What should be improved by the public and private sec- tors in terms of providing equal access to quality education opportunities in Paris?}

This study has shown Paris' efforts to create its own human capital, but even though access to education opportunities in Paris is provided to every child, there are still problems that are creating inequalities in the population that prevent equal job opportunities, because the quality of the education is not the same in every school. Some of these issues are: first, segregation, because it has been proven that there are achievement gaps among different schools in the region. Second, there is not an evaluation system for the teachers and there is no competition among schools and therefore no pressure to improve the quality.

In most cities growth also implies polarization, but in Paris this has not been so dramatic because in the last 20 years the whole population has upgraded, and now according to the INSEE data of 2007, $22 \%$ of the population belongs to the upper class (higher share than Mexico and Chicago), $22 \%$ to the middle class and $50 \%$ is working class, but the more

${ }^{74}$ CUSHMAN \& WAKEFILED HEALEY \& BAKER., European Cities Monitor., 2005.

${ }^{75}$ PARIS REGION ECONOMIC DEVELOPMENT AGENCY., The attractiveness of Paris Region., 2006., p. 25. 
upper classes, the more segregation occurs and most of the times the risk of brain drain rates is higher.

There are many studies on the higher and lower classes but not so many on the middle class which represents a great potential for the city to develop as high skilled workforce along with the 50\% working class that most of it comes from an immigrate background giving it a great potential as a diverse population, but the problem is that because of the republican focus, assimilation of immigrants into the French culture has prevented the vision of diversity as an advantage for the Human Capital of a Global City as it is seen in Chicago.

We could compare Chicago and Paris in that just like the United States, France is one of the oldest lands of immigrants in Europe. It started recruiting foreign workers in the nineteenth century to remedy an early drop in fertility rates and provide a flexible labor force during the industrial revolution, and Belgians, Poles and Italians came to work in French factories ${ }^{76}$, just like immigration flows came to Chicago to work in the industry and the construction of the city. Since then, France has known two periods characterized by high levels of migration: the 1930s and the 1960s. After the war, France recruited foreign workers from Southern Europe and immigrants from its former colonies in North and sub-Saharan Africa and South-East Asia started to arrive. In 1973, France stopped soliciting foreign labor except for seasonal worker and high skilled workers.

There are social inequalities in the French education system, achievement Gaps among schools in the Paris Region have been found. The most disadvantaged schools are the ones in neighborhoods where students come especially from immigrant backgrounds ${ }^{77}$.

French migration policy remains restrictive and official discourse repeatedly calls for the fight against illegal migration. In this context, public

76 GUIRAUDON, Virgine., Developments in French Politics., Palograve., 2005., p. 154.

77 DURU-BELLAT, Marie., Social Inequality in French Education., 2006. 
opinion often believes that immigrants are not welcome, and this makes the integration of immigrants more difficult. Also immigrants are politically excluded and so cannot be disconnected from their feeling of social exclusion and being «second-class» and this fact prevents Paris of creating a self confident, high skilled workforce.

French sociologists Kathy Crapez and Marie Duru-Bellat argue, educational inequality is a matter of acute concern in France as it is in most democratic countries. If both school effects and classroom effects contribute in important ways to the formation of social inequalities among students. One of the factors most strongly correlated with inequalities in achievement is the social composition of the student body. High performing schools are more often, on average, establishments which enroll students from socially advantaged backgrounds according to the studies. Marie Duru-Bellat shows that just having a senior manager for a father instead of a manual worker adds $10.5 \%$ to the chance of completing primary school «on time», and having a mother who holds at least the baccalaureat (instead of a lower level vocational qualification) improves chances by $11.5 \%$. $54 \%$ of immigrant children taken as a group do not repeat a grade in primary school as against $76.3 \%$ of other children.

In the $1989,90 \%$ of children from managers' or teachers' homes entered the three-year baccalaureat program compared to only 42 per cent of manual workers' children. According to Marie Duru-Bellat, 63\% of students (per generation) should pass the Baccalaureat. Political aim is $80 \%$ but $50 \%$ dropes out or fails on the first year of University. School cannot be blamed for this largely social game, inequalities in choices arise mainly form social structure, but it is how school is organized which allows these choices to pull children into different streams of programs of unequal effectiveness and value. But what school is more directly and clearly responsible for is inequalities in achievement, because this gap tends to grow rather than decline over the successive stages of education, contributing to create social inequalities.

High focus on the city center produced poor, vulnerable, isolated banlieues just like the immigrant's neighborhoods where beginner teachers 
are sent. There is not a system of evaluation of teachers and also their promotions are based on seniority and not on their merit or performance.

One of the principal tasks of French state education is to offer everyone the opportunity to succeed and to raise their social status. As the work of the French sociologist Pierre Bourdieu has shown, not only does school not succeed in correcting social inequality, but it contributes to ensuring it continues. By treating pupils on principle as if they were equal, it in fact advantages «the privileged», those whose socialization in the family has already prepared them for learning ${ }^{78}$.

Faced with this phenomenon, the necessity of implementing a policy of positive discrimination was gradually impressed on the authorities and resulted in the creation of educational priority zones (ZEP) in 1981, extended into priority educational networks from 1998. Based on the idea that, to be fair, it is essential «to give most to those who have least», areas where the school failure-rate is high and which stand out for their social and economic problems - particularly the outer suburban estates of the big cities - have been given additional human and financial resources.

By 2000, two-thirds of the foreign workers worked in services that are also situated in urban centers. Today, over a third of the immigrant population lives in Paris and its surrounding suburbs. The more affluent leave this areas and that reinforces segregation and discrimination creating vulnerable zones and schools with a poor vulnerable majority of students, just like in Chicago and Mexico, even though the word "poor» means something different in each city because the richer is the city, the more money it puts in education and so poverty levels are relative and ca not be easily compared.

French government provides education opportunities for all Paris children, but the city must think of what it should learn from cities with different systems like Mexico and Chicago to innovate and analyze how to

${ }^{78}$ CRAPEZ, Kathy., Taking up the challenge of equal opportunities., 2006. 
improve quality and level of the whole education system, because being a highly centralized prevents competition among schools to upgrade the quality in all schools. Paris also needs to take advantage of its multi-ethnic society because of the presence of immigrants and see it as an advantage. Children of Immigrant background have access to education but they need to have better quality in order to be able to provide them with the necessary tools to take advantage of the jobs a global city can offer.

Education is what generates upward social mobilization. The idea of «declassement» (losing a class level) causes fear and it is hard, therefore school choosing is an important decision for the future. But as we have seen, in Paris public schools localized in privileged areas have better qualified teachers and more attractive programs, curriculum and options, for example, art, music and «European Classrooms» with subjects like history and math in other languages. Also privileged areas have more private schools. So, even after 20 years of ZEP there is segregation and inequalities because it took a long time to the Ministry of Education to react to the pressure of the parents' mobilization.

A decision has to be made by the government to either support the republican model or the open more to the market model, where competition can pressure the public system to increase quality. But, if the decision is to continue to have a highly centralized system and keep implementing and working on the republican model, some changes need to take place immediately. First, quality must be the same in every public school. Second, immigration is a fact that can't be denied anymore and it needs to be approached from the point of view that diversity is not a problem, but an opportunity to bring cultural heritage into the classroom, where teaching French cultural heritage in the system is also very important to include, because it explains a big part of the gaps in school achievement and social mobilization.

The more established and more mature cities offer a number of undisputed advantages, they also bring with them the highest costs, they are expensive to attract students but Paris has managed to attract a great part of the international and highly educated young people. It only needs to realize that it does have a working class (including immigrants and their 
children) that is underdeveloped and could be seen as an advantage for a workforce such as diversity. It is also important to close the achievement gaps among schools to lower the social inequalities in Paris by improving the quality in ZEP Zones, not segregating all young professors in the schools with the poorest achievements and trying to produce opportunities for students to find a job after the postgraduate education.

Also as James Scott says, the map is never the territory, and that what the state «sees» is only a very small slice of reality, this is why decentralization process was implemented but still Private participation in education and the lack of civil organizations to close these achievement gaps leave the State without competitors that encourage them to improve the quality in the programs and systems in order for Paris to create a capable and efficient workforce that keeps it competitive in the global era.

\section{CONCLUSION}

A city's intellectual capital is key to its business readiness. A highly educated pool of qualified and talented individuals is essential not only to the staffing needs of companies doing business in the city but also to business's ability to drive innovation. An educated populace will also have an impact on a city's quality of life by providing support for cultural institutions and the arts ${ }^{79}$.

If all children have access to a high-quality education, they will be able to take advantage of the jobs that a Global City can offer and they will all become more productive citizens and better consumers, improving the economy of the city and their community. But when the government is more focused on attracting human capital, it loses resources and attention to develop their own potential. In addition, because of insufficient taxes and large sudden immigration flows, the government lacks the capability to provide equal and quality education to all children, without taking

${ }^{79}$ Cities of opportunities., Price Water House Coopers., 2007., p. 10. 
advantage of a population that is a big potential human capital. This is when we need civil organizations fill this gap by providing services to increase education opportunities and helping create better policies. The best way keep improving the education quality and equal opportunities is to create consensus. The government and the civil organizations must work together in order to make the best decisions to reform the financial formula for the education funds and to upgrade the quality of the education provided in the Global Cities.

Through this study we have been comparing the three cities and we are able to agree that rapid immigration flows and sprawling with a lack of a proper infrastructure to receive and educate immigrants, have created vulnerable neighborhoods around the three cities, with a difficult access to quality education opportunities.

Paris was taken as an example of the opposite case of Mexico City in terms of the public-private role in providing quality education opportunities. French education system is highly centralized, therefore, in Paris the participation of the government grants education, whereas in Mexico City most of the population that receives access to quality education and presents lower drop-out rates comes from private or civil organizations. In this case study, Chicago would be in the middle position with a synergic interaction between the government and the private and civil organizations to provide education opportunities.

Equal and quality education opportunities should be the government's role to provide, along with and all kinds of investment in human capital development in order to be competitive and assure growth. But it is civil organizations', citizens', business' and government's task to be co-responsible of the formation of a competitive society that can take advantage of the opportunities that a global city can offer.

For established cities, the findings should strike a cautionary note that the competition is at their heels. For cities on the move, there are opportunities to learn important lessons from their established counterparts. Taking in consideration the cities selected for this case study and 
comparing them we could abstract the points that could be advantages for the others to implement.

\section{What Could Chicago and Mexico Learn from Paris?}

That equal access to quality education and a well organized, free, mandatory and education system upgrades population's social mobility even when growth of cities tends to create polarization and allows to quickly implement actions to improve the quality of education such as the ZEP program.

\section{What Should Mexico and Paris Should Learn from Chicago?}

Communication and synergy between public and private sectors results a better social policy making, more funding and pressures the improvement of the quality of the education system by combining the civil organization's expertise and the government's power. Also that immigration can be seen as a diversity advantage to create a society that will adapt and impact better to the global system, driving change and innovating to be more competitive.

\section{What Should Chicago and Paris Could Learn from Mexico?}

According to the OECD's PISA 2007 study mentioned before in chapter 2, countries with a balanced Public and private education create a healthy competition that improves quality. Mexico's mix of an important participation of both public, private schools and civil organizations have found ways to build a more dynamic and cooperative society where community development involves more actors than just a government-citizen relationship. These actors are socially responsible enterprises, intellectual elite, media, social and religious civil organizations and citizens get together to fill the government's gaps in providing services and try to promote social policies. 


\section{The Undeveloped in Development: the Potential}

The fermeture of cities to the poor and immigrants, creates exclusion and social problems as a result from unequal opportunities in basic services that global cities need to offer such as education, housing, health, jobs, etc. In Paris it creates the tension in the banlieues; In Chicago, it leads to discrimination and in Mexico this closeness is a result form the indifference of all the sectors to poverty that makes it stay and grow, increasing the gap among social classes. This is when civil organizations are important actors, because the impact of social groups is in their ability to influence public opinion and media, because by attracting the necessary attention, there is a big chance for policy making.

So, in order to create their own human capital starting by providing equal quality education opportunities, global cities should be aware of is that are the following points: First, make sure the funding financial formula is appropriate to improve quality in disadvantaged neighborhoods in order to close achievement gaps. Second, is to analyze the possibility of having a mediating institution that establishes objectives and demands results from the government to improve equality and quality in education.

But the most important vision, in terms of the creation of human capital, is to think of low socio-economic children population -including immigrants - not as a problem, but a as an opportunity, as a potential to create a global city's innovative and diverse human capital able to take the jobs a Global City has to offer. Better education leads to better jobs and which results into more purchasing power and more taxes, activating and improving economy of the city and the region.

As the editorialist David Brooks argued in April 2008 in the New York Times, "The globalization paradigm emphasizes the fact that information can now travel 15,000 miles in an instant. But the most important part of information's journey is the last few inches - the space between a person's eyes or ears and the various regions of the 
brain. Does the individual have the capacity to understand the information? Does he or she have the training to exploit it? Are there cultural assumptions that distort the way it is perceived?».

The real issue that needs to be understood is the incapacity of adaptation of a society to a global system that no longer demands quantity but quality, therefore the aim of every government should be the development of a qualified human capital and the best and fastest way to achieve this is by creating a consensus among sectors that produces effective policy making. This means create and attract but also retain Human Capital, providing a livable and city with the resources to keep a healthy, creative and innovative workforce and community. 